\title{
Mechanical Control of Rodents by using Wire-Box and Glue Traps in Sugar Cane Plantations at Sohag Governorate, Egypt
}

\author{
Abd El-Aleem S.S. Desoky ${ }^{(1)}$; Abdel - Latief A. Abazaid ${ }^{(2)}$; Mahmoud M. K. Ali ${ }^{(3)}$ \\ ${ }^{(1)}$ Plant Protection Department (Agricultural Zoology), Faculty of Agriculture, Sohag University \\ ${ }^{(2)}$ Sugar Crops Research Institute, Agriculture Research Center \\ ${ }^{(3)}$ Post Graduate Student, Plant Protection Department, Faculty of Agriculture, Sohag University \\ abdelalem2011@gmail.com \\ DOI: 10.47760/cognizance.2021.v01i01.001
}

\begin{abstract}
These studies were carried out during two successive years (2017-2019) at Sohag Governorate (Gazert Shandweel Village Located at $15 \mathrm{~km}$ North of Sohag District). In this study, wire-box and glue traps were used to control rodents attacking Sugar cane plants. The results showed that the number of rodents caught during the 2017-2018 season was 45 individuals using wire-box traps and 73 individuals by glue traps, and the results in the second year 2018-2019 show that the number of rodents caught by wire-box traps was 65 individuals. and 78 individuals with glue traps. Both data in Table $(1,2)$ showed that the glue traps were the highest rodent species captured from the thicker traps and most suitable for the house mouse, $M$. musculus.
\end{abstract}

Keywords: wire-box traps, glue traps, rodents, Sugar cane, M. musculus

\section{Introduction}

Rodents attack sugar cane and sugar beet from the beginning of planting until harvest, which leads to a decrease in juice quality, sucrose percentage and productivity per feddan (feddan $=1.038$ acres). As well as the productivity of sugar per feddan in all growing seasons. The annual loss in sugar cane crop caused by A. niloticus was estimated by $5-8 \%$ in weight. The proportions of rat damaged mill able stalk averaged $23.99 \%$ and of dead stalks (due to damage) $7.17 \%$ in non-baited fields while in baited fields, rat damaged mill able stalks averaged $13.53 \%$ and of dead stalks 3.85\% (Porguez \& Barredo, 1978). Rodent damage to sugar cane in Upper Egypt was estimated by 20 to $40 \%$ reduction in yield, and 30 $\%$ in final sucrose in the infested stalks of sugar cane (Abazaid, 1990).

Rat trapping may be an effective rodent management tool for the following reasons: It is mainly necessary to identify, survey and control pest species. Locking up rodent pests is often better than using poisons. Traps prevent rodents from dying in hard-to-reach places and causing an odor problem. There is no chance of accidental or secondary poisoning of non- 


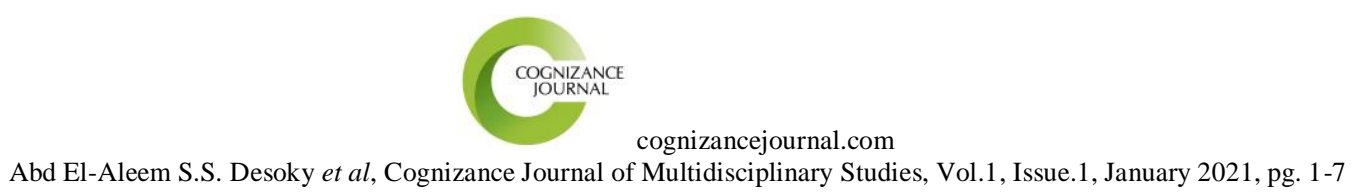

target animals. Traps can be used in situations where poison are not permitted or recommended. Very useful for managing the residual pests that live after the poisonous taste. Tripathy et al.,(2017). This study aims at a comparative study of mechanical control by using wire-box and glue traps in sugar cane plantations.

\section{Materials and Methods}

These studies were carried out during (2017-2018) (2018-2019) at Sohag Governorate (Gazert Shandweel Village Located at $15 \mathrm{~km}$.North of Sohag District) Two feddans were chosen randomly cultivated with sugar cane (30) traps ( 15 Wire traps -15 glue traps) were baited with bread and set up in 10 rows every month at $6 \mathrm{pm}$ and examined each morning for three successive nights were baited with bread and set up in 10 rows every month at $6 \mathrm{pm}$ and examined each morning for three successive nights. Trapped rodents were transferred to the laboratory for identified according to Osborn and Helmy (1980) Records were made for the date and number of individuals collected from each rodent species The percentage of each species was determine.

\section{Results and Discussion}

Evaluation of the efficacy of two rodent traps (wier traps-glue traps) for rodent control. This method is safe to environmental without pollution and not costly and higher than for reduce rodent population density. Frantz and Padula (1983) proved an laboratory study addressing the mode of action of glue entrapment on lab mice, and the behavior of confined lab mice around glue traps. Their results are important in that they provide insight into The interaction between mice and glue Traps, A discussion of the materials used as sticky adhesives for rodent and bird glue traps and repellents is provided by Fitzwater(1982). Corrigan (1994) stated that many factors are likely to affect the efficacy and repellency of glue traps against rodents within real world biological and men- biological factors.

Data in table (1) and figure (1) show the caught number of the different species of the field rodent in winter, Spring, Summer and Autumn in Sohag Governorate, through 2017- 2018 for wire-box traps were (7-9-13 and 19 individual) respectively with total 45 individual on other hand the caught number of the different species of for glue traps were (14-17-22 and 20 individual) respectively with total 73 individual. 
Table (1) Total numbers of rodent species captured per season when used wire-box and glue traps under field conditions during 2017/2018.

\begin{tabular}{|c|c|c|c|c|c|c|c|c|c|}
\hline \multirow[b]{2}{*}{ season } & \multirow{2}{*}{ Month } & \multicolumn{4}{|c|}{ Wire- traps } & \multicolumn{4}{|c|}{ Glue- traps } \\
\hline & & I & II & III & Total & I & II & III & Total \\
\hline \multirow{3}{*}{ Winter } & December & 1 & 1 & $\mathbf{0}$ & 2 & 1 & 4 & $\mathbf{0}$ & 5 \\
\hline & January. & 1 & 1 & $\mathbf{0}$ & 2 & $\overline{\mathbf{0}}$ & 4 & $\mathbf{0}$ & 4 \\
\hline & February & 1 & 2 & $\mathbf{0}$ & 3 & 2 & 3 & $\overline{\mathbf{0}}$ & 5 \\
\hline \multicolumn{2}{|l|}{ Total } & 3 & 4 & $\overline{\mathbf{0}}$ & 7 & 3 & 11 & $\overline{\mathbf{0}}$ & 14 \\
\hline \multirow{3}{*}{ Spring } & March & 2 & 1 & $\mathbf{0}$ & 3 & 2 & 4 & $\mathbf{0}$ & 6 \\
\hline & April & 2 & 2 & $\mathbf{0}$ & 4 & 1 & 4 & $\mathbf{0}$ & 5 \\
\hline & May & 1 & 1 & $\mathbf{0}$ & 2 & 1 & 4 & 1 & 6 \\
\hline \multicolumn{2}{|l|}{ Total } & 5 & 4 & $\mathbf{0}$ & 9 & 4 & 12 & 1 & 17 \\
\hline \multirow{3}{*}{ Summer } & June & 3 & 1 & $\mathbf{0}$ & 4 & 2 & 5 & 1 & 8 \\
\hline & July & 2 & 3 & $\mathbf{0}$ & 5 & 2 & 5 & $\mathbf{0}$ & 7 \\
\hline & August & 2 & 1 & 1 & 4 & 2 & 5 & $\mathbf{0}$ & 7 \\
\hline \multicolumn{2}{|l|}{ Total } & 7 & 5 & 1 & 13 & 6 & 15 & 1 & 22 \\
\hline \multirow{3}{*}{ Autumn } & September & 2 & 3 & $\mathbf{0}$ & 5 & 2 & 5 & $\mathbf{0}$ & 7 \\
\hline & October & 3 & 2 & 1 & 6 & 1 & 6 & $\mathbf{0}$ & 7 \\
\hline & November & 3 & 2 & $\overline{\mathbf{0}}$ & 5 & 1 & 5 & $\mathbf{0}$ & $\overline{6}$ \\
\hline \multirow[t]{3}{*}{ Total } & & 8 & 7 & 1 & 16 & 4 & 16 & $\mathbf{0}$ & 20 \\
\hline & Overall total & 23 & 20 & 2 & 45 & 17 & 54 & 2 & 73 \\
\hline & Percentage & 51.11 & 44.44 & 4.04 & & 23.29 & 73.97 & 2.79 & \\
\hline
\end{tabular}

Signs.: $\mathrm{I}=A$. niloticus

II $=$ M. musculus

$\mathrm{III}=$ R.r.frugivorus 


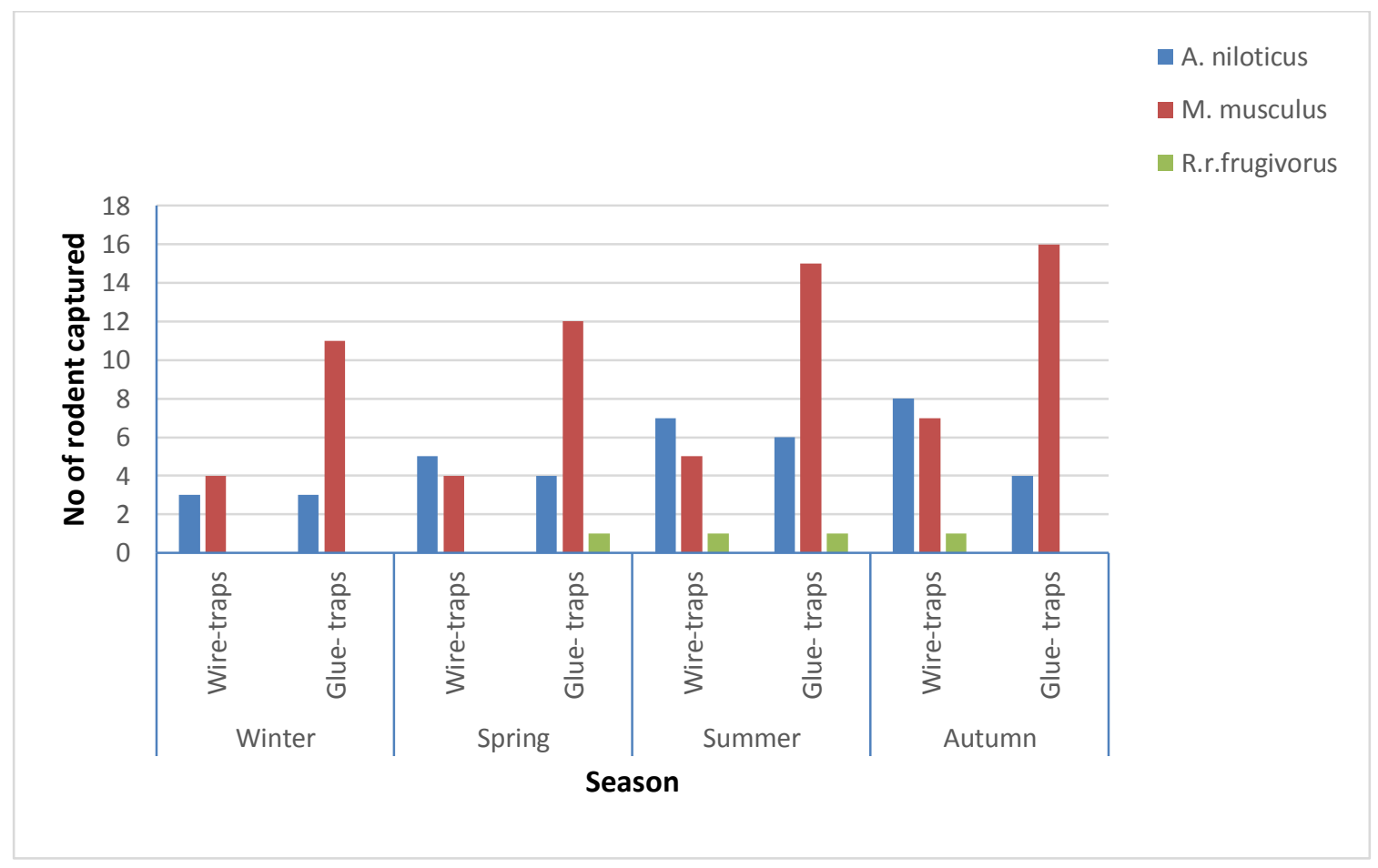

Figure (1) Total numbers of rodent species captured per season when used wire-box and glue traps under field conditions during 2017/2018.

Data in table (2), figure (2) and photo (1) show the caught number of the different species in Winter, Spring, Summer and Autumn through 2018- 2019 for wire-box traps were ( 10- 18 - 19 and 18 individual) respectively with total 65 individual. In the cause of the glue traps caught number of the different species were (15-18- 24 and 21 individual) respectively with total 78 individual. Both data in table (1,2) proved that the glue traps were the higher of rodent species captured than wire-box traps and most suitable for house mouse, M. musculus L.A discussion of the material used as sticky adhesives for rodent and bird glue traps and repellents is provided by Fitzwater (1982). Corrigan ( 1988) stated that it is not Known whether or not pheromones play a negative (or positive) role in The interaction and repeated captures of mice on glue traps. However negative impact does not, seen as likely at least with juvenile captures , as when multiple captures occurred, the capture was often entirely made up of juveniles Corrigan (1994) stated that many factors are likely to affect the efficacy and repellency of glue traps against rodents within real world biological and non- biological factors.- Desoky (2013) found that mechanical control methods achieved great success in rodent control as compared chemical control. The percent of reduce in with rodent active burrows population by using mechanical Control methods ranged between 93-20\% in deep 
irrigation, $87.20 \%$ in handing destroy and $52-60 \%$ in trap methods, This method is safe to the environment with not costly and higher than for reduce rodent population density.

Table (2) Total numbers of rodent species captured per season when used wire-box and glue traps under field conditions during 2018/2019.

\begin{tabular}{|c|c|c|c|c|c|c|c|c|c|}
\hline \multirow[b]{2}{*}{ Season } & \multirow{2}{*}{ Month } & \multicolumn{4}{|c|}{ Wire- traps } & \multicolumn{4}{|c|}{ Glue- traps } \\
\hline & & I & II & III & Total & I & II & III & Total \\
\hline \multirow{3}{*}{ Winter } & December & 2 & $\overline{1}$ & $\mathbf{0}$ & 3 & 2 & 3 & $\overline{\mathbf{0}}$ & 5 \\
\hline & January. & 2 & $\mathbf{0}$ & $\mathbf{0}$ & 2 & $\mathbf{0}$ & 4 & $\mathbf{0}$ & 4 \\
\hline & February & 4 & 1 & $\mathbf{0}$ & 5 & 1 & 4 & 1 & 6 \\
\hline \multicolumn{2}{|l|}{ Total } & 8 & 2 & $\mathbf{0}$ & 10 & 3 & 11 & 1 & 15 \\
\hline \multirow{3}{*}{ Spring } & March & 4 & 1 & $\mathbf{0}$ & 5 & 2 & 2 & $\mathbf{0}$ & 4 \\
\hline & April & 4 & 1 & 1 & 6 & 1 & 4 & 1 & 6 \\
\hline & May & 3 & 3 & 1 & 7 & 2 & 6 & $\mathbf{0}$ & 8 \\
\hline \multicolumn{2}{|l|}{ Total } & 11 & 5 & 2 & 18 & 5 & 12 & 1 & 18 \\
\hline \multirow{3}{*}{ Summer } & June & 4 & 1 & $\mathbf{0}$ & 5 & 3 & 5 & $\mathbf{0}$ & 8 \\
\hline & July & 4 & 1 & 1 & 6 & 3 & 4 & 1 & 8 \\
\hline & August & 4 & 3 & 1 & 8 & 3 & 5 & $\mathbf{0}$ & 8 \\
\hline \multicolumn{2}{|l|}{ Total } & 12 & 5 & 2 & 19 & 9 & 14 & 1 & 24 \\
\hline \multirow{3}{*}{ Autumn } & September & 4 & 2 & $\mathbf{0}$ & 6 & 2 & 5 & $\mathbf{0}$ & 7 \\
\hline & October & 3 & 2 & $\mathbf{0}$ & 5 & 1 & 5 & $\mathbf{0}$ & 6 \\
\hline & November & 4 & 2 & 1 & 7 & 2 & 6 & $\mathbf{0}$ & 8 \\
\hline \multirow[t]{3}{*}{ Total } & & 11 & 6 & 1 & 18 & 5 & 16 & $\mathbf{0}$ & 21 \\
\hline & Overall total & 42 & 18 & 5 & 65 & 22 & 53 & 3 & 78 \\
\hline & Percentage & 64.62 & 27.07 & 7.07 & & 28.23 & 67.95 & 3.85 & \\
\hline
\end{tabular}

Signs.: $\mathrm{I}=A$. niloticus

$\mathrm{II}=$ M. musculus

$\mathrm{III}=$ R.r.frugivorus 


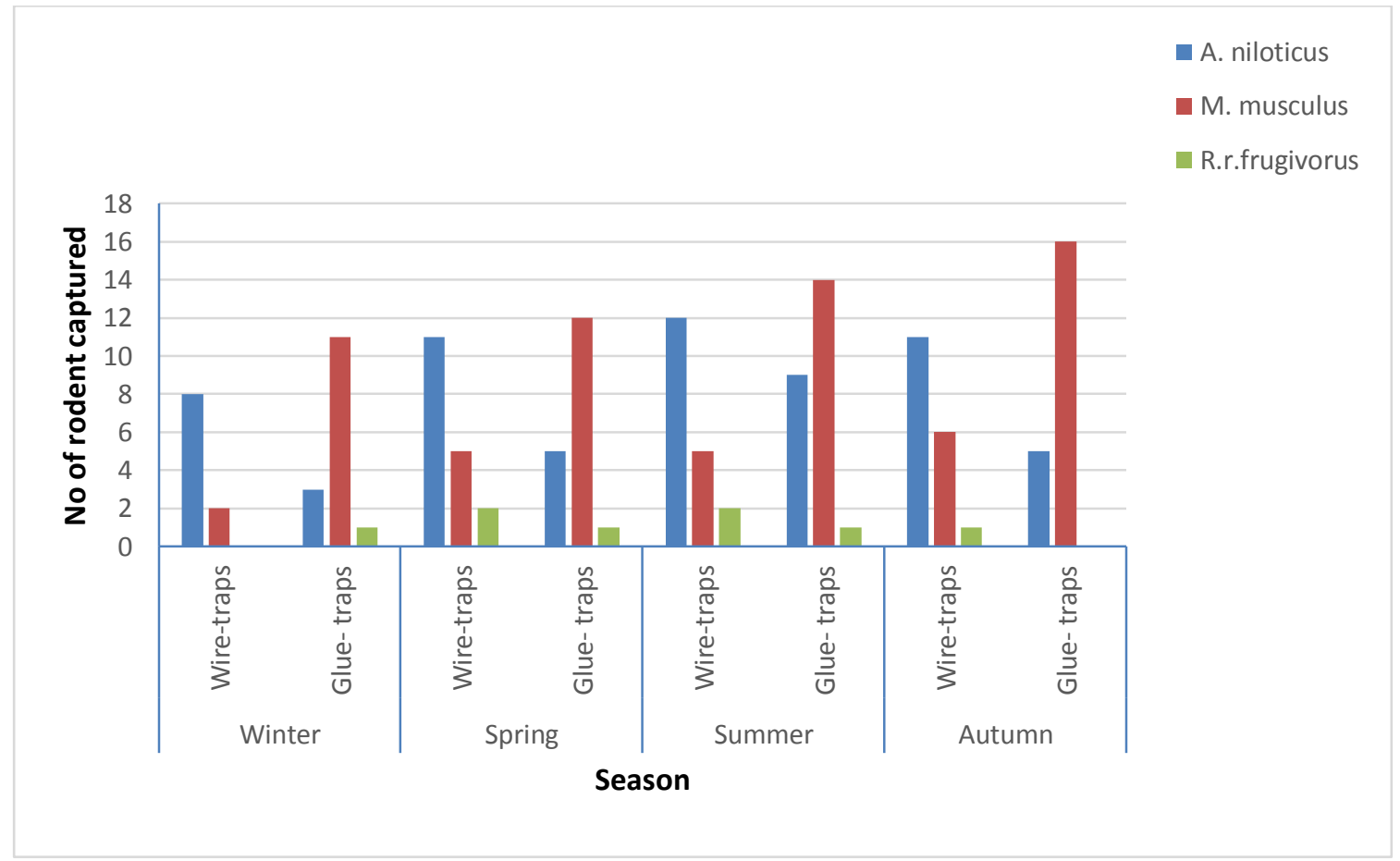

Figure (2) Total numbers of rodent species captured per season when used wire-box and glue traps under field conditions during 2018/2019.

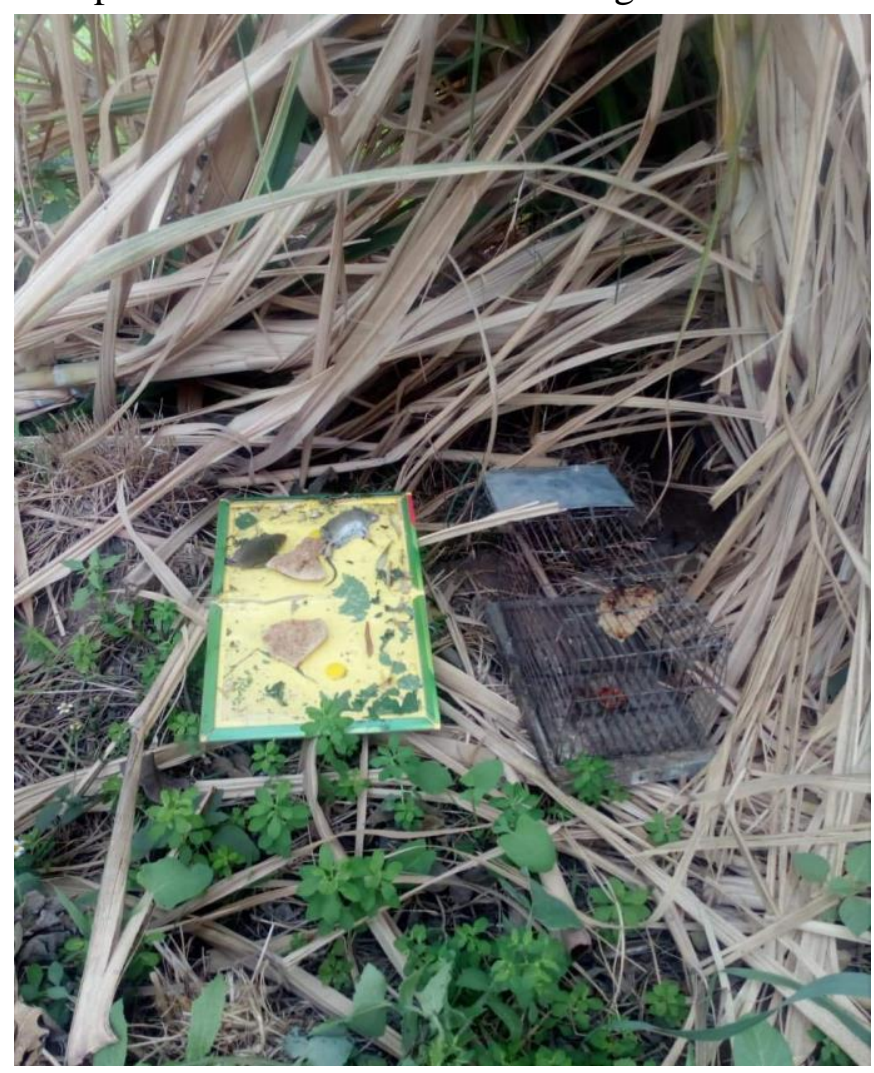

photo (1) wire-box and glue traps used in the current study.

Generally: glue traps are preferred to control the small size and age of rodents that attack sugar cane crops. 


\section{References}

[1]. Abazaid, A.A. (1990). Efficiency of some common used rodenticides and some alternatives against rodent in Qena Governorate. M.Sc. Thesis, Fac. Agric. Assiut Univ., Pp. 93.

[2]. Corrigan, R. M.(1988). Multiple catch traps: Trapping strategies. Pest Control Technology. Vol. 16 (9):45-50.

[3]. Corrigan, R. M. (1994). Glue Traps and Real World Research. Pest Control Technology. Vol. 22 (3):74- 76.

[4]. Desoky, A.S.S. (2013): Evaluation of chemical and mechanical control to reduce active burrows for Arvicanthis niloticus in Sohag Governorate, Egypt, Journal of Environmentally Friendly Processes: Volume-1-issue-1-june-2013.

[5]. Fitzwater, W. D. (1982). Bird Limes and Rat Glues-Sticky Situations. Pages 17-20 in Proceedings Tenth Vertebrate Pest Conference, R. E. Marsh, ed. Univ. of California, Davis, CA.

[6]. Frantz, S. C. and C. M. Padula.( 1983). A laboratory test method for evaluating the efficacy of glue boards for trapping house mice. Pages 209-225 in Vertebrate Pest Control and Management Materials: Fourth Symposium, ASTM STP 817, D. E. Kaukeinen, ed. American Society for Testing and Materials, Philadelphia, PA.

[7]. Osborn, D.J. and I. Helmy (1980). The contemporary land mammals of Egypt (including Sinai).Published by field museum of National Historg. London, field and Zoolgy, New series, Nol's: 569P.

[8]. Porquez P.H. and F.C. Barredo (1978). Rat damage survey in the Victorias mill district. Victories Agricultural Research Reports 16(21):44-52.

[9]. Tripathy, R.S; B. K. Sahoo and Miss G. Sahoo (2017). Integrated rodent pest Management in field and stores, ENVIS Centre of Odisha's State of Environment Hosted by Forest \& Environment Department, Orissa Sponsored by Ministry of Environment, Forests \& Climate Change, Govt of India. 